\title{
Late-onset fungal keratitis from Candida glabrata after penetrating keratoplasty
}

\section{Queratitis fúngica de inicio tardío por Candida glabrata posterior a queratoplastia penetrante}

\author{
Jorge L. Domene-Hickman ${ }^{*}$, Jaime Torres-Gómez¹, Jorge E. Valdez-García1, \\ Julio C. Hernández-Camarena ${ }^{1}$, Gustavo Ortiz-Morales ${ }^{1}$ and Jorge L. Domene Hinojosa ${ }^{2,3}$ \\ ${ }^{1}$ Tecnológico de Monterrey, School of Medicine and Health Sciences; ${ }^{2}$ Vision Maker, Centro Médico Hidalgo; ${ }^{3}$ Centro Médico Nacional Noreste. \\ Monterrey, N.L., Mexico
}

\begin{abstract}
Purpose: To report the case of a late-onset fungal keratitis two months after a penetrating keratoplasty (PKP). Case: $A$ 24-year-old male underwent a PKP on his left eye for advanced keratoconus, without complications. Two months later, corneal infiltrates were apparent and empiric treatment was initiated. As corneal infiltrates progressed, two corneal cultures and a corneal biopsy were performed, all negative. A second corneal biopsy was performed, reporting Candida glabrata. The keratitis was successfully treated with topical, intrastromal and intracameral injections of amphotericin B. Posterior neovascularization of the corneal graft was treated with intrastromal and subconjunctival injections of anti-vascular endothelial growth factor. A second PKP was performed and a secondary cataract developed and was removed. Two years later the patient still has a corrected distance visual acuity of 20/20 in his left eye. Conclusion: This case shows the importance of corneal biopsy and an aggressive therapy in cases of recalcitrant keratitis after a PKP.
\end{abstract}

Key words: Fungal. Keratitis. Candida. Glabrata. Keratoplasty. Amphotericin.

\section{Resumen}

Propósito: Reportar el caso de queratitis de inicio tardío de origen fúngico 2 meses después de una queratoplastia penetrante (QPP). Caso: A un paciente de sexo masculino, de 24 años, se le realizó una QPP en el ojo izquierdo por queratocono avanzado, sin complicaciones. A los 2 meses presenta infiltrados corneales, y se inicia tratamiento empírico. El infiltrado progresó y se realizaron dos cultivos y una biopsia corneal, con resultados negativos. En una segunda biopsia corneal se evidenció Candida glabrata. Se logró un tratamiento exitoso con anfotericina B tópica, intracamerular e intraestromal. La neovascularización del injerto corneal se trató con anti factor de crecimiento endotelial vascular intraestromal y subconjuntival. Se realizó una segunda QPP en conjunto con cirugía de catarata secundaria. A los 2 años, el paciente tiene una agudeza visual corregida para distancia de 20/20 en el ojo tratado. Conclusión: La biopsia corneal y la terapia agresiva son claves en el tratamiento de casos de queratitis refractarias después de una QPP.

Palabras clave: Fúngica. Queratitis. Candida. Glabrata. Queratoplastia. Anfotericina.

Correspondence:

*Jorge L. Domene-Hickman

Ave. Morones Prieto, 3000

Date of reception: 03-03-2019

Date of acceptance: 05-09-2019

C.P. 64710 , Monterrey, N.L., Mexico

E-mail: jorge_domene @ hotmail.com

(http://creativecommons.org/licenses/by-nc-nd/4.0/).
Rev Mex Oftalmol (Eng). 2020;94(6):257-261

www.rmo.com.mx

Published by Permanyer. This is an open access article under the CC BY-NC-ND license 


\section{Introduction}

The cornea is the most frequently transplanted tissue in the world, with more than 185,000 transplants performed worldwide during 2012-2013'.

The complications subsequent to penetrating keratoplasty (PKP) are of great importance, as they can be devastating for visual prognosis. A known complication is infectious keratitis. The number of fungal infections post-PKP due to contaminated donor tissue has been increasing ${ }^{2}$.

Here we present a case of fungal keratitis with atypical presentation after PKP, refractory to initial antifungal treatment, as well as its management.

\section{Case report}

A 24-year-old male medical student, with a history of advanced keratoconus in the left eye, attended the Vision Maker Cornea Service in Monterrey, Mexico. He did not refer other relevant history.

At his initial visit, he had a distance-corrected visual acuity (DCVA) of 20/20 in the right eye and $20 / 200$ in the left eye. On slit-lamp examination of the left eye, the cornea showed signs of previous corneal hydrops, with a deep central leukoma and generalized haze.

We decided to perform a PKP. The cornea came from a 21-year-old donor with normal endothelial cell density $\left(3,170\right.$ cells $\left./ \mathrm{mm}^{2}\right)$, from the Lions Eye Bank in Tampa, Florida. The time from death to procurement was of 6 hours and 3 minutes, and the time from procurement to surgery was of 6 days. The donor had no relevant history. The surgery was performed without complications and he was prescribed doxycycline $100 \mathrm{mg}$ orally for 15 days, topical moxifloxacin $0.5 \%$, and dexamethasone sodium phosphate $0.1 \%$ every 4 hours for 30 days. In the second month, topical treatment was started only with loteprednol $0.2 \%$ every 8 hours.

Sixty-seven days after PKP, the patient returned to consultation because his left eye was red and painful. Upon examination, his distance-uncorrected visual acuity (DUCVA) in the left eye was $20 / 50$. Slit-lamp examination of the left eye revealed conjunctival hyperemia and a $1 \times 1 \mathrm{~mm}$ stromal infiltrate with a feathery appearance, located near the 9 o'clock suture (Fig. 1). No epithelial defect was observed. The suture was removed and $0.2 \%$ loteprednol was suspended. Gatifloxacin $0.5 \%$ and netilmicin $0.3 \%$ were prescribed every hour.

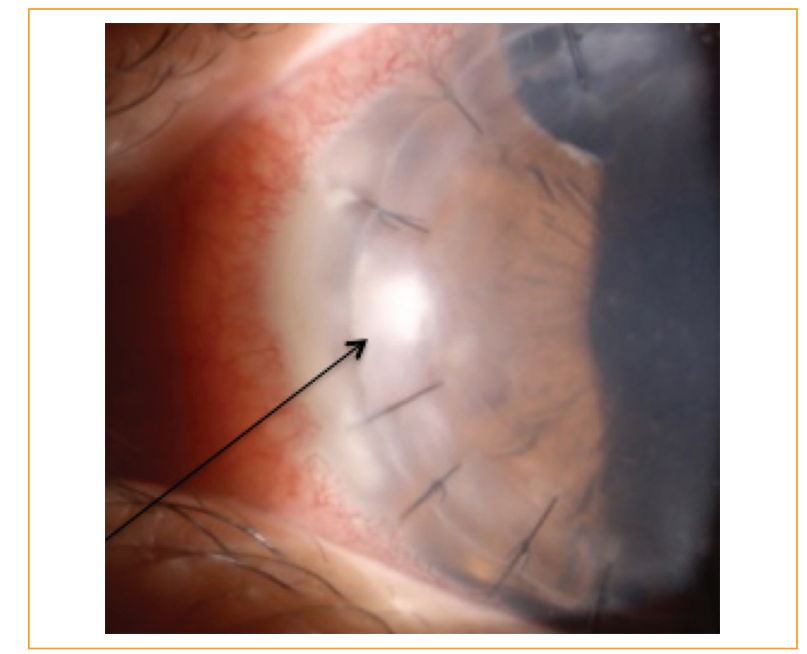

Figure 1. The arrow shows the initial corneal infiltrate.

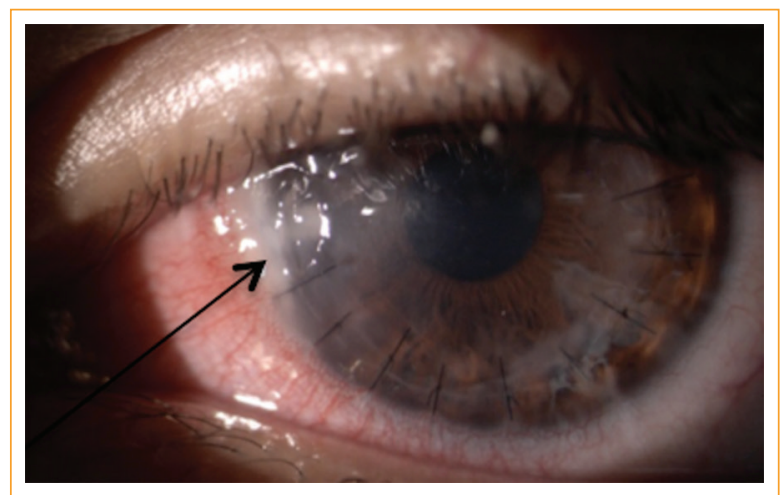

Figure 2. The arrow shows the infiltrated area. A small epithelial defect is observed.

With no improvement after 72 hours, topical treatment was changed to natamycin $5 \%$, fortified vancomycin $5 \%$, fortified ceftazidime $5 \%$, and voriconazole $1 \%$. In addition, corneal scraping was performed for culture and Gram stain.

By day 4, the infiltrate had increased in size (Fig. 2), and voriconazole $200 \mathrm{mg}$ PO every 12 hours was added to the regimen.

On the $16^{\text {th }}$ day, the patient showed no signs of improvement with the prescribed management and the culture was reported as negative. A corneal biopsy and conjunctival graft were performed, without complications.

Thirty days after onset, the biopsy was negative and slit-lamp examination showed intense corneal edema and enlargement of the corneal infiltrate, involving both the corneal graft and the patient's cornea from 6 to 9 o'clock. Visual acuity at that time was counting 
fingers at 1 meter. A new corneal biopsy was taken and sent to a different laboratory. Corneal collagen crosslinking was performed the same afternoon. An ultraviolet light lamp (VEGA CBM-X-Linker, CSO, Firenze, Italy) was used, with Ricrolin plus riboflavin (Sooft, Italy) impregnated for 15 minutes, followed by 9 minutes of ultraviolet radiation $\left(10 \mathrm{~mW} / \mathrm{cm}^{2}\right)$.

Six days later, the biopsy result was positive for Candida glabrata. We switched to a regimen of fluconazole $100 \mathrm{mg}$ PO every 12 hours, topical fluconazole $2 \%$, topical amphotericin B $0.5 \%$, and topical natamycin $2 \%$ every hour. This treatment was maintained every hour for a week, every 2 hours during the second week and then every 4 hours for the next 2 months. A dose of intracameral $(50 \mu \mathrm{g} / \mathrm{ml})$ and intrastromal $(25 \mu \mathrm{g} / \mathrm{ml})$ amphotericin B and a dose of subconjunctival fluconazole $(2 \mathrm{mg} / \mathrm{ml})$ were also administered.

A week later, the patient went to the emergency room with severe pain in his left eye. On examination, a $1 \mathrm{x}$ $1 \mathrm{~mm}$ central corneal perforation was observed, already sealed (Fig. 3), and angle-closure glaucoma was diagnosed. Mannitol 20\% IV was administered with a dose of $1.5 \mathrm{mg} / \mathrm{kg}$ in 45 minutes, and a topical combination of timolol $0.5 \%$, brimonidine $0.2 \%$ and dorzolamide $2 \%$ was administered every 2 hours, which improved symptoms within hours.

During the next 3 months, there was an improvement in symptoms (pain) and signs (stromal infiltrate and epithelial defect). During this period, intrastromal and subconjunctival injections of anti-vascular endothelial growth factor (VEGF) (bevacizumab, Roche Pharma Inc.) were administered every month in doses of $0.6 \mathrm{cc}$ to $100 \mathrm{mg} / 4 \mathrm{ml}$, due to the intense vascularization observed. The left eye developed a complete corneal leukoma, with $360^{\circ}$ vascularization. Slit-lamp examination revealed a flat anterior chamber and a sealed and stable $1 \times 1 \mathrm{~mm}$ corneal perforation. Intraocular pressure remained within normal limits and stable during this period.

At this point, it was decided to perform a second PKP (8 months after the first transplant). During the procedure, intrastromal and subconjunctival anti-VEGF was applied.

Six months after the second PKP, the corneal graft remained clear (Fig. 4). During this period, two subconjunctival and intrastromal injections of anti-VEGF were administered. DUCVA was 20/100 due to an anterior and posterior subcapsular cataract observed on examination. One year after the second PKP, the last corneal suture was removed and phacoemulsification + toric

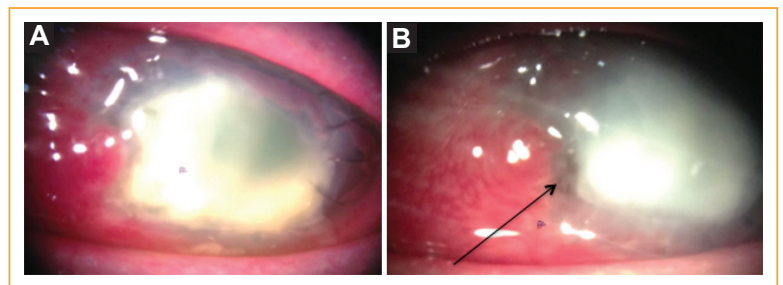

Figure 3. Intense corneal edema, vascularization, and signs of infection. A: The conjunctival graft is in place. B: The arrow shows the corneal perforation, already sealed.

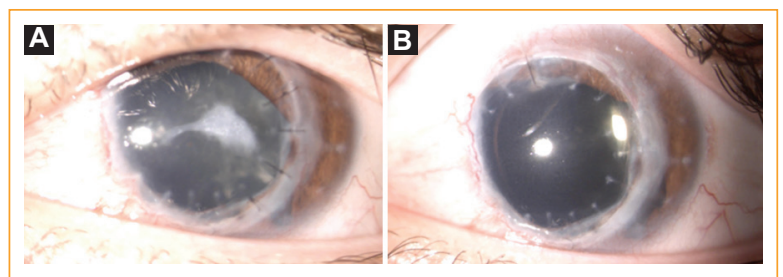

Figure 4. Second clear corneal graft with no evidence of infection. A: A cataract is observed. B: The corneal graft remains clear after cataract surgery.

intraocular lens implantation was performed. One week later, the patient was asymptomatic and with a DCVA of 20/20 (Fig. 4). Two years after his initial visit, the patient remained asymptomatic, with a DCVA in the left eye of $20 / 20$, a refraction of $-0.25 \mathrm{DS} /-2.00 \mathrm{DC} \times 160^{\circ}$, a clear corneal graft and an intraocular pressure of $14 \mathrm{~mm} \mathrm{Hg}$.

\section{Discussion}

This case represents a rare but serious complication after PKP. Fungal infections after PKP are often aggressive and potentially lead to endophthalmitis. A reference center in Mexico reported that only $44.83 \%$ of infectious keratitis cultures reported a pathogen, and the incidence decreases if antibiotics or antifungals have been used ${ }^{3}$. Therefore, a possible cause of negative cultures is the previous use of these drugs, as described in this case.

In this scenario, corneal biopsy becomes an invaluable tool for diagnosis. In our case, C. glabrata was reported in a second biopsy, after two negative cultures, which delayed the start of an effective therapeutic regimen.

C. glabrata was considered a non-pathogenic species of the normal flora, but recent reports show that it 
has a higher mortality and virulence than other non-albicans Candida species, in addition to having a lower susceptibility to fluconazole and other azoles. Fortunately, this pathogen does not show the same resistance to topical amphotericin B. Furthermore, the intrastromal and intracameral administration of amphotericin $B$ has been shown to be safe and effective in the treatment of severe fungal keratitis refractory to topical antifungals ${ }^{4,5}$.

The reported risk of infectious keratitis after PKP ranges between 1.76 and $11.9 \%$. In a study carried out in Mexico, $88.4 \%$ of the cases of infectious keratitis were of bacterial origin, with Staphylococcus epidermidis being the most frequent pathogen $(27.9 \%$ of the cases). The isolated cases of fungi were responsible for $10.91 \%$, and C. glabrata was not isolated in any case $^{3,6}$.

Recent reports show an increase in post-PKP fungal keratitis. Developed countries have reported a fungal etiology in $45.5 \%$ of their post-PKP infectious keratitis. This could be due to the higher proportion of lamellar keratoplasties, where fungal keratitis seems to predominate ${ }^{2}$.

Risk factors for corneal graft infection include epithelial defects, recurrent herpetic keratitis, ocular surface diseases, suture-related problems, graft failure, contact lens use, corneal graft hypoesthesia, and eyelid abnormalities. In our patient, there was no history of ocular trauma, systemic or ocular disease (apart from keratoconus), the graft was in good condition, but the suture was infected. Because the patient was a medical student on a clinical rotation at a university hospital, a nosocomial infection cannot be ruled out, even when the patient denied ocular trauma and exposure to fluids or blood.

Another possible mechanism of infection is late-onset donor-recipient transmission of $C$. glabrata after corneal transplantation. C. glabrata has been reported worldwide as a cause of infectious keratitis after PKP or lamellar transplantation. Our patient reported symptoms 67 days after surgery, and there are reports of C. glabrata keratitis up to 146 days after surgery?.

It is recommended to perform a fungal culture of the graft border in cases where infection transmission from donor tissue is suspected. In our practice, the graft border is retained for 15 days and if the patient shows no evidence of infection, it is discarded. Since our patient showed symptoms 2 months after PKP, we were not able to perform a culture of the border of the donated cornea. To the best of our knowledge, no Mexican ophthalmology tertiary care center performs routine cultures of the donor's corneal border, but this case demonstrates its potential value.

Our patient received a total of 6 injections of anti-VEGF. Neovascularization of the cornea can cause inflammation, edema, scarring and fibrosis, as well as an increased risk of graft rejection ${ }^{8}$.

The use of anti-VEGF antibodies in fungal keratitis, such as bevacizumab, has been reported to inhibit neovascularization without adverse effects on fungal load or innate immunity, in contrast to steroids and other anti-inflammatory drugs, which can enhance fungal replication in keratomycosis ${ }^{9}$.

With the recent increase in fungal infections, we should consider reopening the debate about the cost-benefit of adding antifungal agents to preservation media. Voriconazole or amphotericin B supplementation in Optisol GS vials has been shown to decrease Candida spp contamination. without causing significant endothelial toxicity when the appropriate dose is used $^{10}$.

\section{Conclusion}

Fungal microorganisms such as Candida spp. are usually responsible for late-onset keratitis after PKP, even months after the procedure. Recently, with the increase in anterior and posterior lamellar keratoplasties, a similar increase in fungal keratitis has been observed after the procedure. Therefore, in these cases, an early corneal biopsy should be performed if the cultures are negative and the clinical course is unfavorable. In the case of C. glabrata keratitis, intracameral and intrastromal injections of amphotericin B are highly effective, since this pathogen has shown high susceptibility in previous studies. In cases of keratomycosis, the use of subconjunctival and intrastromal anti-VEGF is effective in reducing graft neovascularization without the secondary effects of corticosteroids (inhibition of innate immunity and increased fungal burden). Our experience shows the importance of an aggressive medical therapy in conjunction with surgical management, which can improve the visual prognosis. This case shows the potential benefit of adding antifungal agents to the current media used for corneal preservation.

\section{Conflicts of interest}

The authors declare no conflicts of interest. 


\section{Ethical disclosures}

Protection of human and animal subjects. The authors declare that no experiments were performed on humans or animals for this study.

Confidentiality of data. The authors declare that they have followed the protocols of their work center on the publication of patient data.

Right to privacy and informed consent. The authors have obtained the written informed consent of the patients or subjects mentioned in the article. The corresponding author is in possession of this document.

\section{References}

1. Gain $\mathrm{P}$, Jullienne R, He Z, Aldossary M, Acquart S, Cognasse F, et al Global survey of corneal transplantation and eye banking. JAMA Ophthalmology. 2016;134(2):167-73.
2. Davila JR, Mian SI. Infectious keratitis after keratoplasty. Curr Opin Ophthalmol. 2016;27(4):358-66.

3. Hernández-Camarena JC, Bautista-de Lucio VM, Chirinos-Saldaña P, Navas A, Ramírez-Miranda A, Graue-Hernández, EO. Queratitis infecciosas: tendencias microbiológicas y sensibilidad a antibióticos. Segundo Reporte Anual del Grupo de Estudio de Microbiología Ocular del Instituto de Oftalmología "Conde de Valenciana". Rev Mex Oftalmol. 2013; 87(2):100-9.

4. Le Q, Wu D, Li Y, Ji J, Cai R, Xu J. Early-onset Candida glabrata interface keratitis after deep anterior lamellar keratoplasty. Optom Vis Sci. 2015:92(5):e93-6.

5. Hu J, Zhang J, Li Y, Han X, Zheng W, Yang J, et al. A combination of intrastromal and intracameral injections of amphotericin $B$ in the treatment of severe fungal keratitis. J Ophthalmol. 2016; 3436415.

6. Vajpayee RB, Sharma N, Sinha R, Agarwal T, Singhvi A. Infectious keratitis following keratoplasty. Surv Ophthalmol. 2007;52(1):1-12.

7. Al-Assiri A, Al-Jastaneiah S, Al-Khalaf A, Al-Fraikh H, Wagoner MD Late-onset donor-to-host transmission of Candida glabrata following corneal transplantation. Cornea. 2006;25(1):123-5.

8. Chang JH, Garg NK, Lunde E, Han KY, Jain S, Azar DT. Corneal Neovascularization: An Anti-VEGF Therapy Review. Surv Ophthalmol. 2012; 57(5):415-29.

9. Yuan X, Wilhelmus KR. Corneal neovascularization during experimental fungal keratitis. Mol Vis. 2009;15:988-96.

10. Layer N, Cevallos V, Maxwell AJ, Hoover C, Keenan JD, Jeng BH. Efficacy and safety of antifungal additives in Optisol-GS corneal storage medium. JAMA Ophthalmol. 2014;132(7):832-7. 